\title{
Successful investment and turnaround strategies for distressed shopping centre properties
}

Received: 30 June 2004

\section{Larry Feldman}

is Chairman and CEO of Feldman Mall Properties (formerly Feldman Equities), and known for his depth of experience in all facets of real estate, including development, construction, leasing, management and finance. He is well known for his proven track record of turning around underperforming property through extensive renovation, aggressive promotion and lease-up. Larry is also founder and Chairman Emeritus of the Midtown West Association of New York and a member of the ICSC and NAREIT. He is currently the Chairman of the Buildings \& Grounds Committee and a member of the board of trustees of East Woods School on Long Island.

\section{Abstract}

This paper addresses the formulation and implementation of successful turnaround strategies for distressed retail properties, including key characteristics for potential investment candidates, capital improvement programmes and retenanting programmes designed to make mall properties less susceptible to the loss of major anchor tenants. Attracting and enhancing entertainment-oriented anchors, improving visibility of key tenants, weeding out unhealthy, low-volume or unprofitable stores and attracting junior anchor tenants effectively to 'Wal-Mart proof' mall properties will also be addressed.

\section{Keywords:}

malls, retail, real estate, turnarounds, investment, shopping centres

Larry Feldman

Feldman Mall Properties 1010 Northern Blvd

Suite 314

Great Neck, NY 11021, USA

Tel: +1 5166841239

E-mail: Ifeldman@feldmanequities.com

\section{INTRODUCTION}

Most real estate investors have avoided mall turnaround plays for a variety of reasons, ranging from the fear of retail bankruptcies to the Wal-Mart juggernaut theory. The mall landscape is littered with the names of once-great department stores that have succumbed to bankruptcy or are in the middle of downsizing in an effort to keep afloat. Many malls have suffered substantially as Wal-Mart and Target continue to roll out their superstores. There are approximately 1,200 enclosed retail malls in America and a rough estimate is that one-quarter of these malls are in trouble, at least to some degree. Some malls are witnessing eroding market share while others are experiencing massive vacancies and foreclosure. 


\section{Prime candidates for investment}

\section{Importance of entertainment anchors}

Typical candidates for this paper's turnaround strategy are enclosed malls of 500,000 square feet $\left(\right.$ c. $\left.46,000 \mathrm{~m}^{2}\right)$ and above, that require gross investments (including debt, equity and upgrade costs) ranging from $\$ 25 \mathrm{~m}$ to $\$ 150 \mathrm{~m}$. In almost all cases, the total costs of acquisition and renovation result in a total redevelopment cost well below replacement cost.

Distressed malls can be acquired and renovated at far below replacement cost, and these malls are often in very good locations. Each mall situation is approached by coming up with a comprehensive strategic turnaround plan. The strategic plan almost always involves devising a strategy of 'Wal-Mart proofing' the mall through an aggressive leasing campaign. The number one objective of the leasing campaign is to seek out new anchors and speciality retailers that do not compete with Wal-Mart or the typical power centre down the block.

The strategy involves attracting the right mix of speciality retailers which offer specialised products not available at Wal-Mart. The strategy also combines these speciality retailers with an entertainment anchor such as a multiplex theatre and a series of upscale restaurants.

\section{EXECUTING THE TURNAROUND STRATEGY}

An example of the turnaround strategy is Harrisburg Mall in Harrisburg, PA (see Figure 1). Kravco built the mall in 1969 and then sold it to a publicly traded trust controlled by Kravco and Equitable Life (EQK). Following EQK's bankruptcy in 1999, the

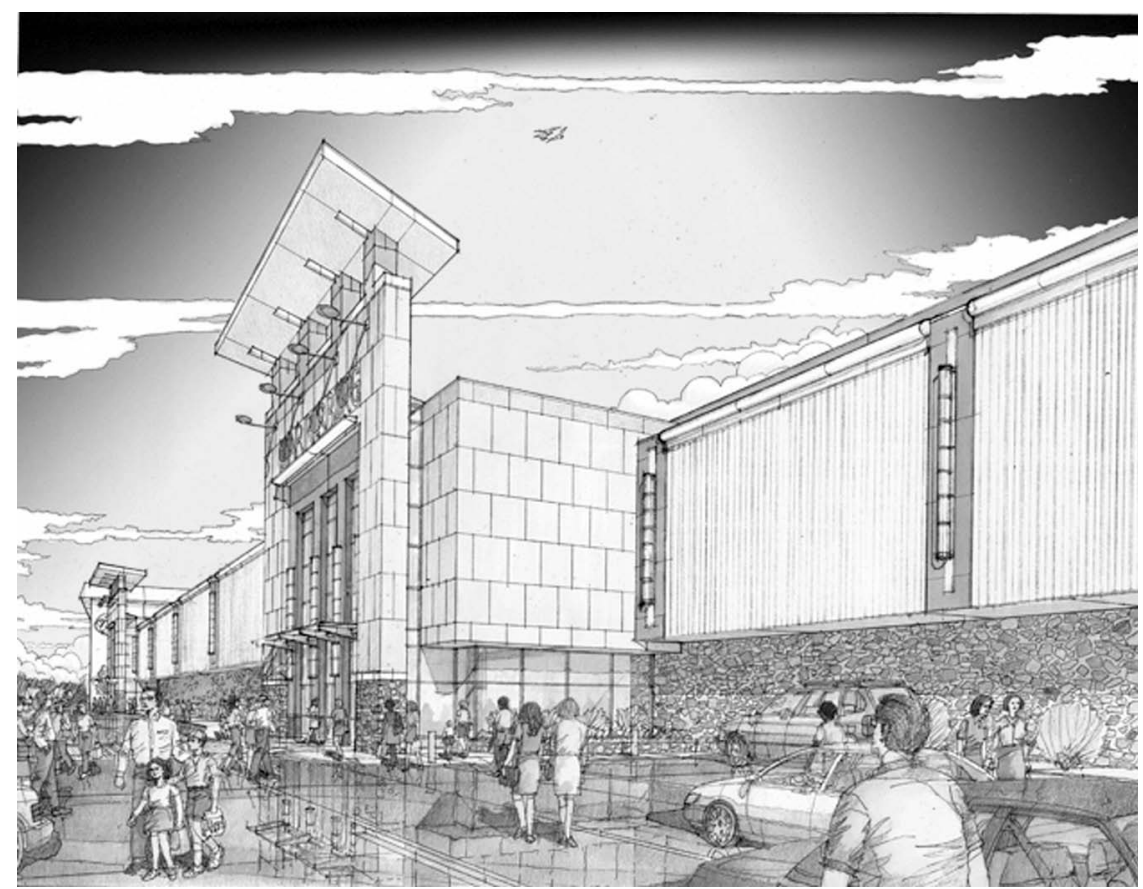

Figure 1: The entrance to the Harrisburg Mall, Harrisburg, PA 


\section{Turnaround strategy in action}

\section{Securing new anchors}

mall was put up for auction. There were no bids, so the mall reverted back to Prudential (the lender), which secured title to the mall with a total debt in excess of $\$ 45 \mathrm{~m}$. In May 2001 JC Penney vacated their store; the JC Penney vacancy, combined with a vacancy by Lord \& Taylor, brought the mall to an effective occupancy of 50 per cent. The property was in grave danger of being demolished for land value.

In 2003 Feldman acquired the foreclosed Harrisburg Mall from Prudential Insurance. Concurrent with the acquisition, Feldman signed two new anchor leases and renewed a lease with a third anchor totalling over 590,000 square feet $\left(\right.$ c. $\left.55,000 \mathrm{~m}^{2}\right)$. The new tenants include Bass Pro Shops, which signed a long-term lease for space vacated by Lord \& Taylor. Bass Pro is renovating and expanding the former Lord \& Taylor store to convert it into a spectacular superstore consisting of approximately 225,000 square feet $\left(\right.$ c. $\left.21,000 \mathrm{~m}^{2}\right)$ of fishing and hunting products. Excluding their flagship store, the Harrisburg store will be the largest Bass Pro store in the nation (see Figure 2). Boscov's department store also signed a long-term lease for the former JC Penney store.

In addition, an existing tenant, Hecht's (a division of the May Company - NYSE: MAY), made a long-term commitment to the mall and extended their lease to 2024. The expansions of Bass Pro and Boscov's will result in an overall mall size of over 900,000 square feet (c. $84,000 \mathrm{~m}^{2}$ ).

Because of the new tourism-related jobs that will be created and the taxes that will be generated, Feldman arranged for a multimillion-dollar grant from the state of Pennsylvania, as well as special tax incentives from Swatara Township, Dauphin County and the local school district. In addition, Feldman arranged for the Pennsylvania Department of Transportation (PENNDOT) to provide a direct exit ramp to the property from Interstate 83.

The purchase price, including buildings and land, was $\$ 17.5 \mathrm{~m}$ or $\$ 20.88$ per square foot. The following is a summary of the Harrisburg Mall transaction.

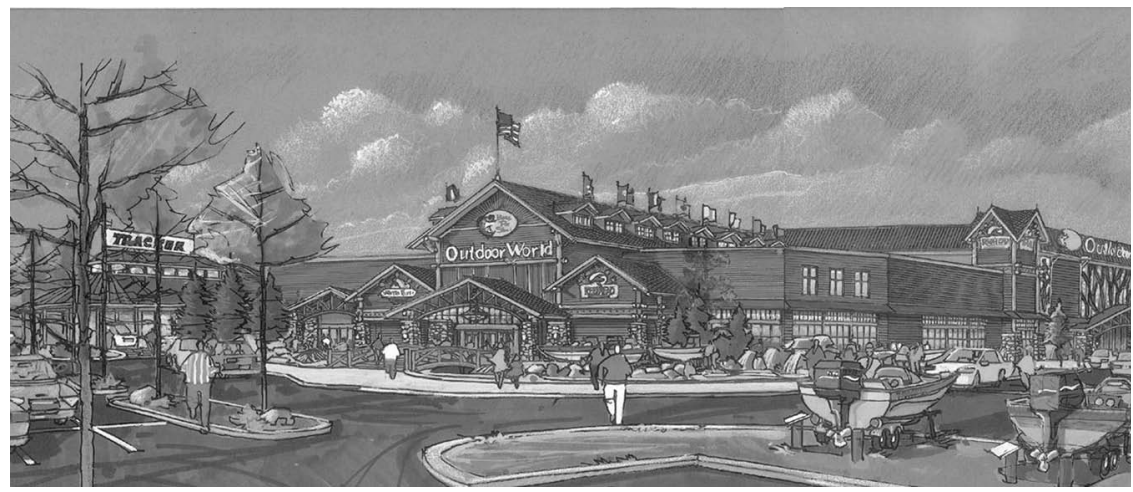

Figure 2: The Bass Pro store at the Harrisburg Mall 


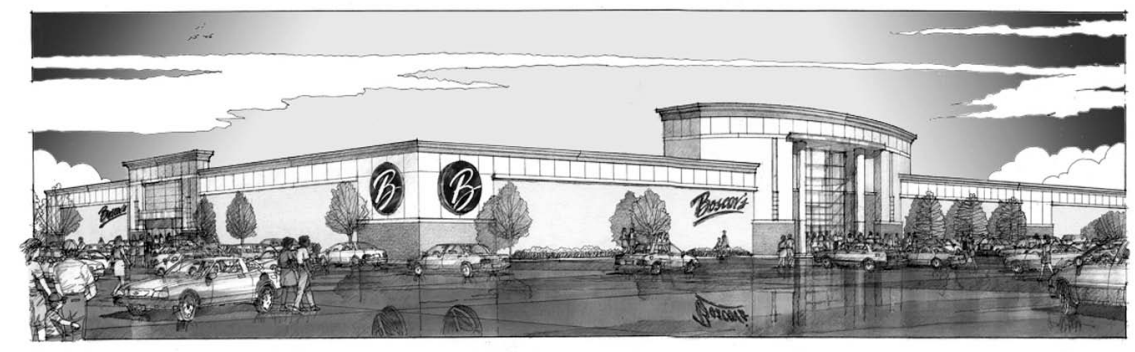

Figure 3: The Boscov's store at the Harrisburg Mall

\section{Bass Pro: A destination retailer}

\section{Junior anchor tenants are key}

- A 225,000 square feet (c. 21,000m²) lease was signed with Bass Pro Shops. Bass Pro is one of the strongest sporting goods retailers in the USA. The typical Bass store averages over $\$ 400$ per square foot per annum in sales. The key reason for this very high level of sales is the fact that Bass Pro Shops is also an entertainment destination. The Harrisburg store will feature a 40,000-gallon aquarium, rock-climbing walls, waterfalls and an indoor shooting and archery range.

- The typical Bass store draws up to 3 million visitors annually. ${ }^{1}$ That figure will make it one of the largest tourist destinations in the state of Pennsylvania.

- Approximately 40 per cent of Bass customers travel an hour or more to get to the store. ${ }^{2}$

- Boscov's has commenced renovation and expansion of a 185,000 square feet (c. 17,000m ${ }^{2}$ ) department store (see Figure 3). With over $\$ 1$ bn in sales, ${ }^{3}$ Boscov's is one of the most successful department stores in the country and is a major advertiser in the Pennsylvania market. It successfully competes with all major discounters.

- Bass Pro Shops is expected to increase shopping traffic to the mall sharply. Estimates are that overall visitor traffic to the mall will increase tenfold from present levels.

- Boscov's, Bass Pro Shops and the May Company have all signed long-term leases with long-term operating covenants.

- The tax incentives and the multimillion-dollar grant from the state will allow the property to undergo a massive exterior and interior renovation. Over $\$ 32 \mathrm{~m}$ in hard costs is being expended to upgrade the mall.

\section{ENHANCING ENTERTAINMENT ANCHORS}

The following is an example of the execution of this strategy. Feldman Equities signed a contract to acquire the Foothills Mall in Tucson, Arizona, in late 2001. Foothills Mall is a mid-sized mall with a series of junior anchor tenants such as Linens 'N Things, Saks Off Fifth Ave., Barnes and Noble, a large Nike factory outlet store, Ross Dress for Less and a 15-screen Loews Cineplex Theatre (see Figure 4). 


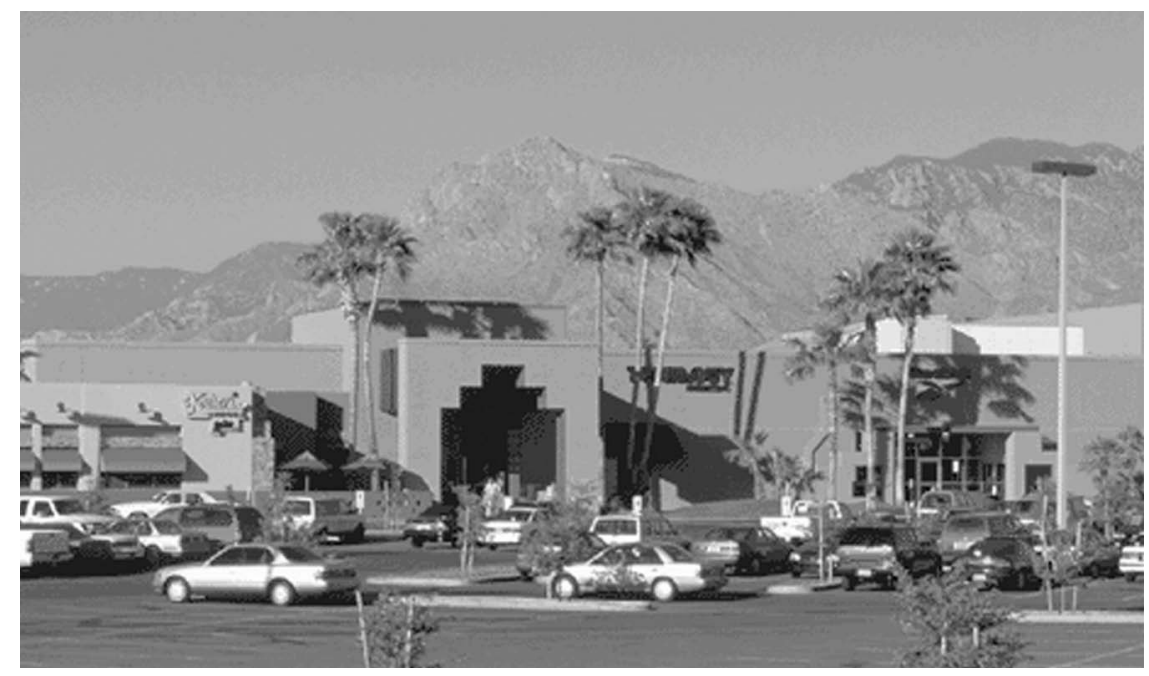

Figure 4: Foothills Mall, Tucson, AZ

\section{Selecting growth markets}

\section{America's cinema love affair}

Foothills Mall is located in one of the hottest growth markets in the USA, in the north-west suburbs of Tucson, but previously suffered from lacklustre shop sales. In spite of mediocre shop sales at the time the mall was purchased, the mall was home to one of the most successful movie theatres in the state of Arizona. During any given week, the Loews cinema at Foothills Mall is attended by tens of thousands of patrons. The bulk of these patrons enter and exit directly through the theatre's existing parking lot entrance, however, and most theatre patrons never enter the mall. With the objective of sharply driving up tenant sales, a very creative real estate deal was concluded which involved providing $\$ 4 \mathrm{~m}$ to the theatre operator, Loews Cineplex, in order to facilitate conversion of all 15 theatres to full stadium seating. In exchange, the existing parking lot entrance will be closed off, and the only entrance to the Loews Cineplex will be through the mall. The conversion to modern stadium seating is expected to boost box-office attendance, and the redirecting of all of Loews patrons into the interior of the mall is expected to have a dramatic effect on overall mall pedestrian traffic. As a result, shop sales throughout the mall are expected to increase sharply.

Over the last few years, when terrorism and war threatened and travel seemed risky, when the economy faltered and the stock market swooned, here is what Americans did: they went to the movies. In 2002 Americans went to the movies, and went again and then went some more. In 2003 America's love affair with the movies continued unabated, with ticket sales approaching the $\$ 10 \mathrm{bn}$ mark despite continued uncertain economic times. ${ }^{4}$ The turnaround strategy ensures that the Loews Cineplex at Foothills Mall will continue to be the finest movie facility in Tucson, and an entertainment destination for years to come. 


\section{Expanding existing sites}

\section{Retail expansion and pad site development}

In addition, in just two years Feldman Equities has arranged for the development of five of six available pad sites at the 508,000square-feet (c. $47,000 \mathrm{~m}^{2}$ ) entertainment and retail centre at Foothills Mall, creating over 50,000 square feet $\left(\right.$ c. $\left.5,000 \mathrm{~m}^{2}\right)$ of new retail space for tenants such as Thomasville Furniture, Fox \& Hound Smokehouse, Compass Bank, Starbucks and the Arizona Central Credit Union. Occupancy at Foothills Mall has climbed up over 97 per cent, with predominantly national credit tenants, and comparable shop tenant sales are growing at double-digit rates.

In addition to the renovation of the Loews Cineplex, two new mall expansions were constructed at Foothills, totalling 26,000 square feet $\left(\right.$ c. $\left.2,000 \mathrm{~m}^{2}\right)$. The expansion areas were leased to Famous Footwear, a discount shoe retailer, Payless Shoes, Radio Shack, EB Games and a series of smaller speciality retailers. The mall is also undergoing a major renovation of its food court and the food court entrance, and its north-west entrance. Selected mall corridors and ceilings were also upgraded for greater customer visibility. A new entrance was built at the mall's south end, and an all-new sign package was installed at the mall's entrances, including a 28-foot main entrance sign with an LED reader board.

A few of the key highlights regarding Foothills Mall are as follows.

- The mall is located in the rapidly growing, high-income northwest suburbs of Tucson.

- It is adjacent to a 210,000 -square-feet (c. $\left.19,000 \mathrm{~m}^{2}\right)$ super Wal-Mart with annual sales of $\$ 100 \mathrm{~m}^{5}$

- A new community college was recently built less than a quarter of a mile away. The campus will initially accommodate 5,500 students and is ultimately sized for 7,000 students.

- One of the mall's key access roads has just undergone a major widening.

- Tourism is a \$2bn-a-year industry in Tucson, ${ }^{6}$ and the mall's location is ideal for capturing a significant portion of Tucson's tourist trade.

- A 2.5 per cent unemployment rate in Tucson is due to the highly affordable housing and a well-educated and relatively young workforce. ${ }^{7}$

- Population in a five-mile radius of the mall grew by 33 per cent from 1990 to $2000 .^{8}$

\section{ATTRACTING JUNIOR ANCHOR TENANTS}

Another element to this strategy is to fill malls with a series of junior anchors with speciality products not found at Wal-Mart stores. This strategy solves three problems at the same time. First, by filling the mall with a series of 'big-box' speciality retailers as anchors, the mall is less dependent on traditional department stores that have been steadily losing market share to the discounters. 
Making malls 'Wal-Mart proof'

\section{Improving property visibility}

Also, by filling the mall with a series of smaller junior anchors, the solvency of the mall is less threatened by the potential bankruptcy of a large department store or a decision by a department store to shut down a particular location. Secondly, by converting the movie theatre to stadium seating and redirecting the patrons inside the mall, the mall has a distinctively different, 'Wal-Mart proof' entertainment-oriented make-up. Thirdly, the cinema anchor has attracted a major base of restaurant tenants such as Outback Steak, Applebee's and a host of other local and regional restaurant operators.

Attracting the right tenant mix is just part of this turnaround strategy. Effective capital investment is also key to the success of a mall turnaround. These investments vary from project to project, but include the renovation of the exterior façade of the mall, the renovation of the mall entrances, an upgrade to the mall's common-area corridors and lighting, resurfacing and restriping the mall's entire parking lot and significantly upgrading the mall's signage.

In addition to renewing profitable high-volume tenants at the best possible market rents, the releasing process also includes weeding out unhealthy, low-volume or unprofitable stores in a proactive way that allows failing tenants to cut their losses by buying out of their leases and applying the resulting short-term income towards incoming tenant inducements.

Successful mall turnaround also includes improving visibility of key tenants and constructing new entrances or implementing ways to improve shopper circulation throughout the property. It also involves intensive marketing programmes geared to the local trade area and promotional activities that ensure a constant flow of events occurring at the mall, such as musical performances, sports promotions, radio station events and hosting other civic and charitable functions.

\section{References}

1. Adib-Yazdi, B. (2000) 'Design leads to outdoor adventure at Bass Pro Shops', Retail Traffic Magazine, 1 July, New York, NY.

2. Shubinski, J. (2004) 'North Las Vegas draws development interest', In Business Las Vegas, 4 June, Las Vegas, NV.

3. DiCarlo, L. (2002) 'Forbes largest private companies', Forbes, 17 July, New York, NY.

4. Sinacola, C. (2004) 'Blackstone Valley's new 14-screen cinema caters to varied crowd', Worcester Telegram \& Gazette, 29 June, Worcester, MA.

5. Claritas, Inc. (2001) Foothills Mall Sales Prospectus, 1 November, Tucson, AZ.

6. Spitz, T. (2004) 'Small town feel-big city amenities', Tucson Lifestyle Magazine, 30 June, Tucson, AZ.

7. Ibid.

8. Ibid 